\title{
PENGARUH POLA HARI HUJAN TERHADAP PERKEMBANGAN PENYAKIT GUGUR DAUN CORYNESPORA PADA TANAMAN KARET MENGHASILKAN
}

\author{
Nurhayati ${ }^{1)}$ dan Aron Situmorang ${ }^{2)}$
}

\begin{abstract}
Effect of weather on the development of leaf fall disease in the yielding rubber estate. This research was conducted in PTP VII Bergen Lampung from July to August for 2005 and 2006 (new leaves period). This research was carried out using survey and experiment methods. Parameters observed in the research were persentages of leaf stage, the number of leaf fall per $\mathrm{m}^{2}$ caused by Corynespora cassiicola and amount of spore distributed in air, daily rainfall amount and number of rain days. Results of the study showed that the pattern of rainfall and number of raindays affected the development of plant's new leaves and leaf fall disease caused by Corynespora. The amount of spores distributed in the air was relatively higher in 2005 observation period compared to 2006 one. The pattern of rainfall and number of rain days also affected the disease severity which was higher in 2005 compared to 2006. Epidemy was occurred when lower rainfall amount taking place intermittently with sunny days in the period of new leave formation.
\end{abstract}

Key words : Corynespora leaf fall disease, rubber, rainfall, numbers of raindays

\section{PENDAHULUAN}

Penyakit gugur daun Corynespora (PGDC) yang disebabkan oleh Corynespora cassiicola merupakan salah satu penyakit karet yang sangat penting, karena penyakit ini dapat mengakibatkan peranggasan tanaman karet sepanjang tahun sehingga pertumbuhan terhambat, penyadapan tidak dapat dilakukan dan bahkan menyebabkan kematian tanaman. Selain menyerang tanaman di lapangan penyakit ini juga menjangkiti tanaman karet yang ada di pembibitan, sehingga dapat mengakibatkan kerugian yang besar. Penyakit ini dapat menyerang daun karet baik yang masih muda maupun yang telah tua (Situmorang \& Budiman, 1984).

Tanaman karet sangat rentan terhadap penyakit gugur daun corynespora pada saat pembentukan daun muda. Stadia daun yang berwarna coklat atau pada saat umur daun sampai 18 hari sejak muncul merupakan stadia daun yang sangat rentan, sehingga apabila pada kondisi ini tanaman terserang $C$. cassiicola dapat mengakibatkan keparahan penyakit sampai 80 persen (Nurhayati et al, 2004).

Menurut Soepena (1986) dan Pawirosoemardjo (2004) serangan Corynespora sangat berpengaruh terhadap pertumbuhan tanaman muda sehingga masa matang sadap terhambat atau diperpanjang 3 sampai 5 tahun atau lebih, atau sama sekali gagal untuk matang sadap. Pada klon GT 1 yang terserang gugur daun selama dua bulan dapat menurunkan produksi getah lebih dari 40 persen dari produksi normal. Serangan berat gugur daun pada tanaman karet klon PPN 2058 dan PPN 2447 di Jawa Tengah mengakibatkan penurunan produksi lateks antara 24 hingga 62 persen (Pusat Penelitian dan Pengembangan Perkebunan Tanjung Morawa, 1988).

Penurunan produktivitas juga terjadi pada klon RRIM 600 yang terserang C. cassiicola. Penurunan produktivitas tersebut berkisar antara 30 sampai 40 persen dengan kerugian mencapai ratusan milyar rupiah per tahun (Anwar et al., 2000). Informasi yang disebutkan sebelumnya merupakan bukti bahwa penyakit gugur daun yang disebabkan oleh jamur tersebut merupakan salah satu penyakit terpenting pada tanaman karet dan bersifat endemis di Indonesia, apabila faktor lingkungan seperti cuaca kondusif dapat berubah menjadi epidemi (Darmono, 2006).

Timbulnya epidemi penyakit gugur daun dapat disebabkan oleh tiga hal utama yaitu klon karet yang rentan, ras patogen yang lebih virulen dan faktor lingkungan/cuaca yang sangat membantu perkembangan penyakit tersebut (Situmorang, 1998). Indonesia memiliki kondisi iklim yang sangat sesuai bagi perkembangan penyakit gugur daun corynespora. Faktor cuaca seperti suhu, kelembaban atau kebasahan

\footnotetext{
${ }^{1}$ Jurusan Hama dan Penyakit Tumbuhan, Fakultas Pertanian, Universitas Sriwijaya, Kampus Inderalaya Ogan Ilir Inderalaya 30662

${ }^{2}$ Balai Penelitian Perkebunan Sembawa
} 
daun serta hujan merupakan faktor yang paling membantu terjadinya epidemi penyakit tersebut

Situmorang \& Budiman (1984) melaporkan bahwa di daerah yang mempunyai curah hujan merata sepanjang tahun atau daerah dengan batas musim hujan dan kemarau yang tidak begitu jelas, patogen ini mengakibatkan kerusakan berat sehingga tanaman meranggas sepanjang tahun. Sebaliknya di daerah yang mempunyai musim kemarau yang lebih panjang dari tiga bulan serangan patogen tersebut tidak mengakibatkan peranggasan sepanjang tahun.

Perubahan iklim global yang berdampak kepada perubahan iklim lokal diyakini memicu perkembangan penyakit gugur daun. Musim hujan atau musim kemarau yang berkepanjangan dapat mengakibatkan terjadinya perubahan perkembangan penyakit. Musim hujan yang berkepanjangan tersebut dapat mengakibatkan terjadinya epidemi penyakit gugur daun Corynespora (Situmorang, 1998).

Penelitian ini ditujukan untuk mempelajari seberapa jauh pengaruh pola hari hujan terhadap perkembangan penyakit gugur daun Corynespora pada tanaman karet yang sudah menghasilkan.

\section{METODE PENELITIAN}

Penelitian telah dilaksanakan di Kebun karet yang sudah menghasilkan di lahan perkebunan PTP VII Bergen provinsi Lampung,, Pertanaman yang diamati adalah klon RRIM umur 6-7 tahun dengan jarak tanam 7x3 meter di lahan seluas 70 hektar (Gambar 1). Penelitian dilakukan selama periode pembentukan daun baru tahun 2005 dan 2006 (selama bulan Juli dan awal Agustus). Dalam penelitian ini digunakan dua metode yakni metode survei dan metode eksperimen. Metode survei dilakukan dalam rangka memperoleh data tentang stadia daun, jumlah daun gugur dan data iklim. Metode ekperimen dilakukan untuk memperoleh data distribusi spora di udara.

Parameter pengamatan dalam penelitian ini adalah persentase stadia daun, jumlah daun gugur/m2, distribusi spora serta pola curah hujan dan hari hujan. Penghitungan jumlah spora dilakukan untuk mengetahui distribusi spora $C$. cassiicola di udara selama percobaan berlangsung. Gelas objek yang telah diolesi dengan gliserin jeli (40 g gelatin+ 130 ml gliserin $+150 \mathrm{ml}$ air) diletakan pada sangkar yang telah terdiri dari plat seng bulat dengan diameter $30 \mathrm{~cm}$. Plat seng tersebut disangga pada bagian tengahnya oleh kayu dengan ketinggian sampai di bawah tajuk pohon. Diletakkan sebanyak 4 sangkar di setiap hektar pada areal perkebunan sesuai mata angin. Adapun luas areal yang digunakan seluas 10 ha yang ditentukan secara acak dari 70 ha hamparan yang ada. Penangkapan spora dilakukan dengan menempatkan sebanyak 4 gelas objek/ sangkar pada setiap hari pada pukul 07.00 WIB dan diambil pukul 07.00 WIB keesokan harinya. Jumlah konidia patogen yang tertangkap pada gelas objek dihitung dibawah mikroskop dengan pembesaran 10 x 10 dengan luas pengamatan $1 \mathrm{~cm}^{2}$. Pengamatan dan penghitungan jumlah spora tersebut dilakukan setiap hari pada periode Juli dan Agustus tahun 2005 dan 2006 (pada

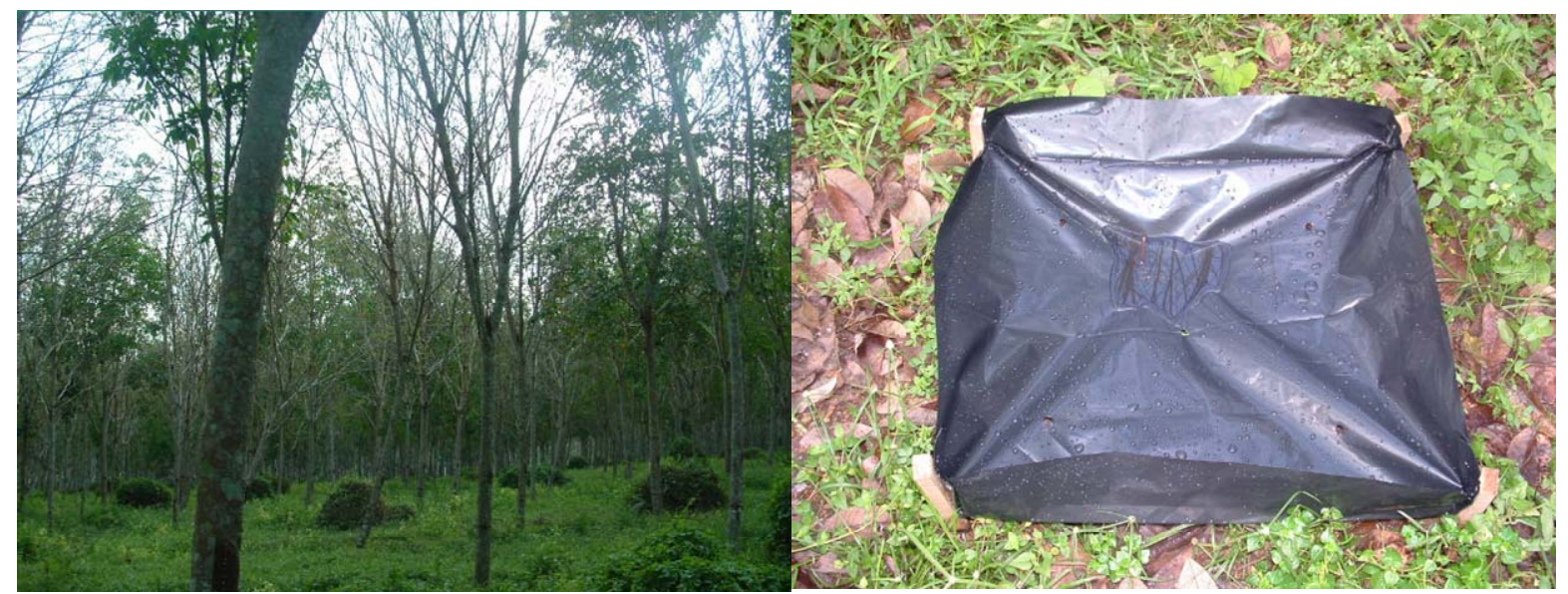

Gambar 1. Lokasi perkebunan tempat penelitian dan alat penampung daun gugur 
saat terbentuknya daun baru).

Data kondisi cuaca dikumpulkan dari Stasiun Klimatologi terdekat meliputi curah hujan dan hari hujan selama bulan-bulan Juli dan Agustus 2004, 2005 dan 2006. Selain itu kondisi cuaca secara kualitatif seperti kondisi cerah atau panas, mendung, berkabut, gerimis dan hujan juga dipantau setiap hari. Kondisi cuaca tahun 2004 diamati sebagai pembanding karena pada tahun ini pada areal tersebut terjadi epidemi penyakit gugur daun corynespora.

Data yang diperoleh dalam dalam penelitian ini, ditata dan dianalisis secara tabulasi serta dilakukan interpretasi.

\section{HASIL DAN PEMBAHASAN}

\section{Hasil}

Pola pembentukan daun muda dan kerentanan daun tajuk terhadap PGDC. Pola stadia daun yang diteliti beragam selama tahun 2005 dan 2006 (Gambar 2). Selama periode pengamatan tahun 2005 dapat dilihat bahwa pada minggu ke tiga Juli 2005 jumlah pucuk dan daun cokelat berturut-turut 15 dan 30 persen dari sampel yang diamati. Pengamatan pertama tahun 2005 ( 9 juli) dimana daun baru mulai muncul. Pada periode pengamatan selanjutnya (minggu ke empat Juli 2005) persentase pucuk
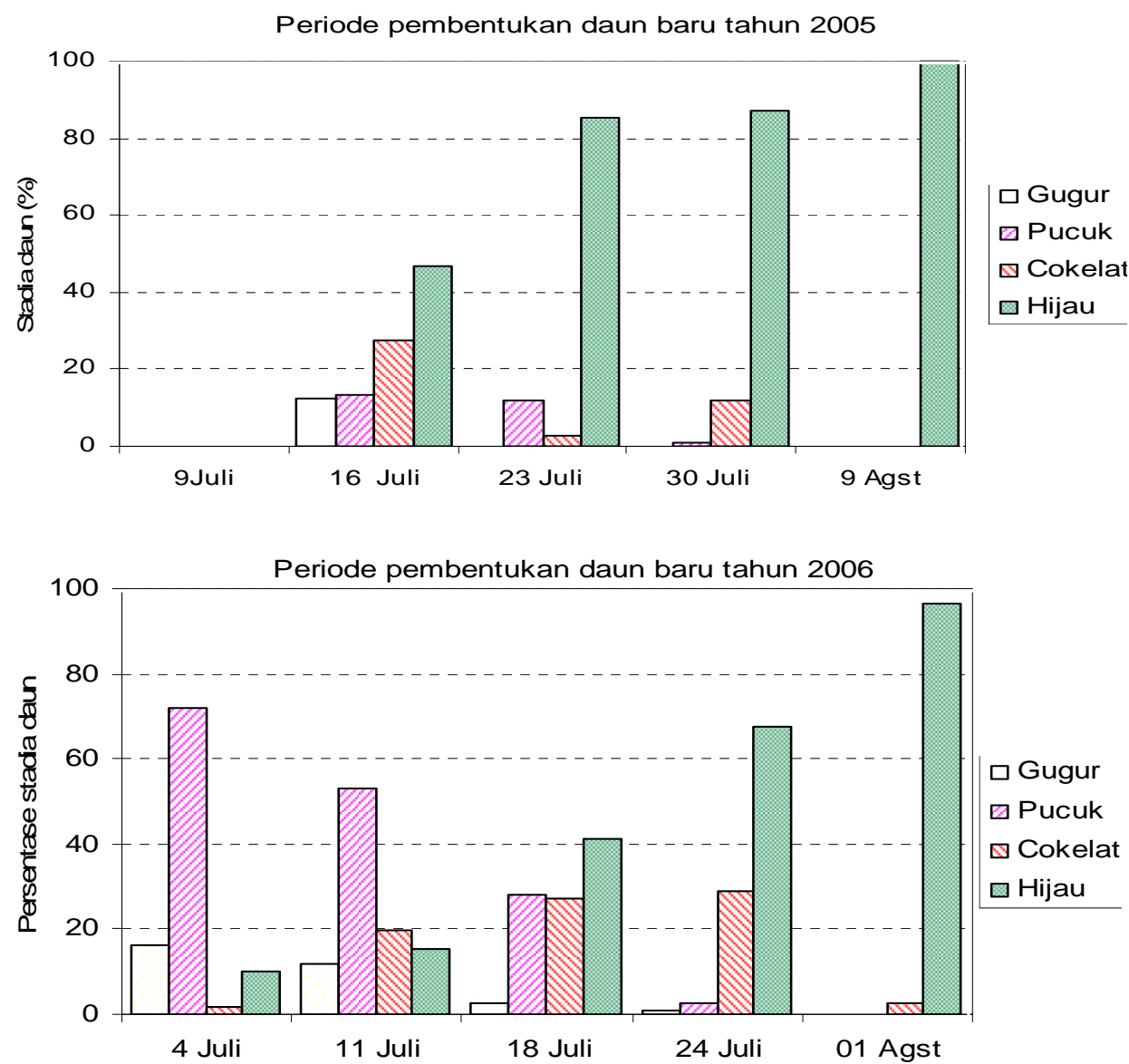

Gambar 2. Keragaman stadia daun selama tahun 2005 dan 2006 
menurun dan daun coklat meningkat. Pada periode ini kebanyakan daun sudah memasuki stadia daun hijau (83 persen dari jumlah pengamatan), sedangkan pucuk hanya tinggal 1 persen, 10 hari kemudian 100 persen daun sudah menjadi hijau.

Pola stadia daun selama periode pengamatan 2006 ternyata sangat berbeda dengan periode yang sama pada tahun sebelumnya. Pada awal Juli 2006 stadia daun yang tertinggi persentasenya adalah pucuk yakni sekitar 71 persen dari jumlah daun yang diamati. Pada periode pengamatan ini hanya 10 persen daun yang berwarna hijau, sedangkan yang berwarna cokelat hanya 2 persen dari jumlah daun yang diamati. Pada pengamatan selanjutnya persentase stadia daun yang masih dalam bentuk pucuk menurun drastis yakni menjadi 28 persen pada minggu ke tiga Juli 2006 dan hanya tinggal 2,5 persen pada minggu keempat. Persentase ini relatif tinggi dibandingkan dengan periode pengamatan tahun 2005. Pada periode minggu ke tiga Juli 2005 persentase daun pucuk hanya 15 persen dari jumlah daun yang diamati (lebih rendah 20 persen dibandingkan angka pada periode pengamatan yang sama dalam tahun 2006).

Perkembangan penyakit gugur daun Corynespora sangat berhubungan erat dengan periode pembentukan daun muda dan keadaan cuaca terutama hari hujan dan curah hujan. Hari hujan dalam penelitian ini dihitung mulai daun baru muncul sampai daun umur 18 hari dimana daun dalam kondisi rentan terhadap patogen sedangkan umur 19 hari daun sudah hijau. Pada Gambar 3 dapat dilihat bahwa pada bulan Juli 2004 jumlah hari hujan 10 hari dengan curah hujan sebesar $178 \mathrm{~mm}$ terjadi pada 18 hari pertama di bulan tersebut yang merupakan periode pembentukan daun karet muda. Pada bulan Juli tahun berikutnya (2005) terjadi perubahan jumlah hujan hanya 7 hari dengan jumlah curah hujan $87 \mathrm{~mm}$, yang mengalami pergeseran waktu turun hujan selama 6 hari. Pada periode pembentukan daun muda tahun 2006 (Juli) kembali terjadi pergeseran pola hari hujan dari curah hujan, di mana hujan mulai terjadi pada hari ke 16 dan hanya ada tiga hari hujan pada saat daun karet masih dalam kondisi kritis ( umur daun kritis sampai 18 hari setelah muncul) dengan jumlah curah hujan hanya $33 \mathrm{~mm}$.

Pola pergeseran curah hujan dan hari hujan tersebut sangat berpengaruh terhadap infeksi C. cassiicola, karena selama periode tersebut pada satu sisi daun berada pada stadium rentan sedangkan pada sisi lain perkembangan jamur berlangsung optimal, dimana pada kondisi tersebut terdapat hujan dengan curah hujan harian yang tidak terlalu tinggi serta suhu berkisar 28-30 C sangat sesuai untuk perkembangan penyakit ini.

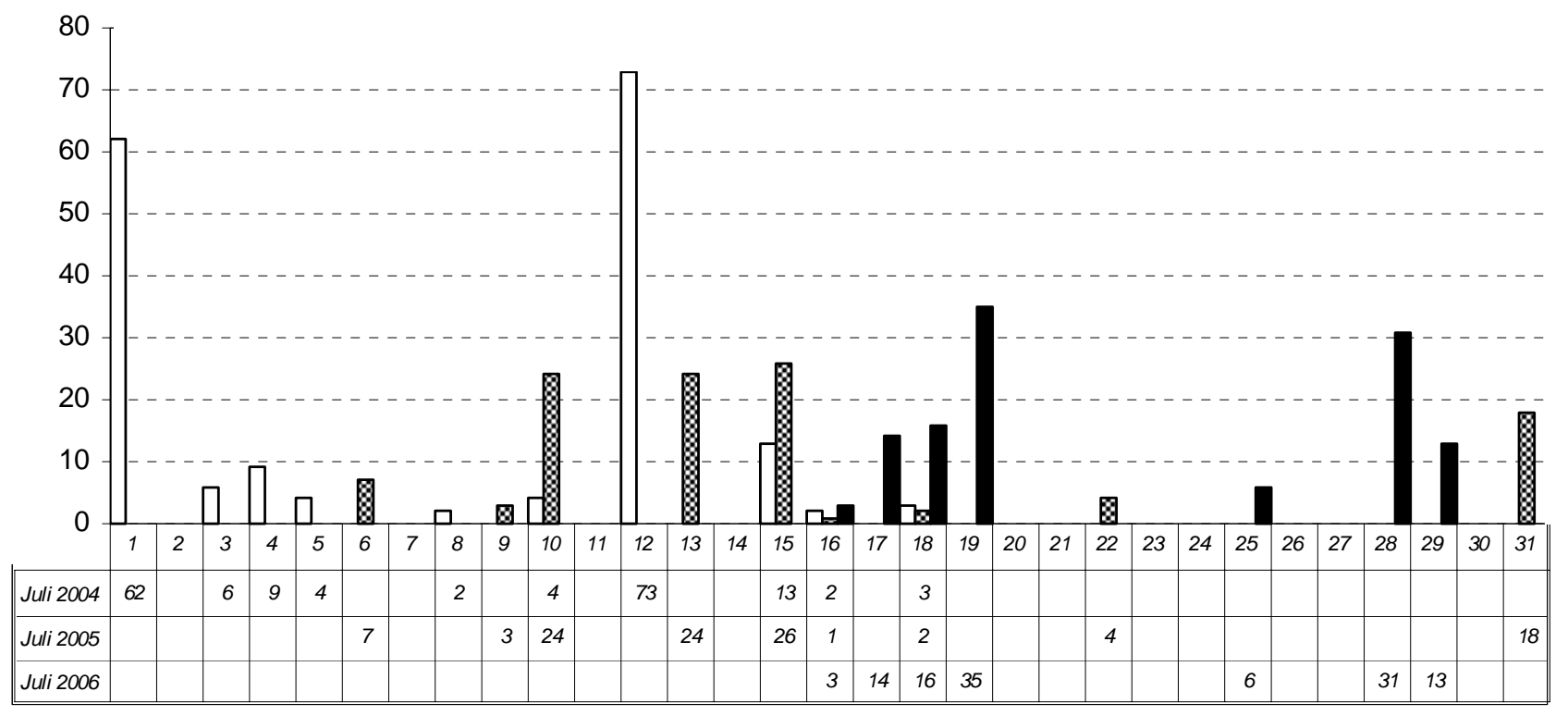

Gambar 3. Pola hari hujan dan curah hujan pada Juli 2004-2006 di PTP VII Bergen 
Pola distribusi spora. Perkembangan penyakit gugur daun selama periode pengamatan ditelusuri melalui pengkajian penyebaran spora di udara pada periode yang sama (Gambar 4). Selama tahun 2005 jumlah spora yang terdistribusi di udara relatif tidak berubah selama paruh awal Juli dibandingkan dengan paruh ke dua bulan yang sama. Pada paruh awal jumlah spora di udara sekitar $5,5 \mathrm{spora} / \mathrm{cm}^{2}$, sedangkan pada paruh kedua di bulan itu adalah $4,6 \mathrm{spora} / \mathrm{cm}^{2}$. Pada periode pengamatan minggu pertama Agustus 2005 jumlah spora di udara naik secara drastis dari 4,6 menjadi 7,6 spora $/ \mathrm{cm}^{2}$, dan bahkan pada minggu ke dua hingga awal minggu ketiga Agustus 2005 jumlah spora di udara meningkat hampir 200 persen yakni menjadi 20 spora/ $\mathrm{cm}^{2}$.

Rata-rata jumlah spora pada tahun 2006 ternyata sangat berbeda bila dibandingkan dengan kebanyakan hasil pengamatan selama periode tahun sebelumnya, kecuali pada periode pengamatan paruh kedua Juli 2006 (sama angkanya dibanding periode yang sama tahun 2005). Pada pengamatan awal jumlah spora di udara hanya $0,6 \mathrm{spora} / \mathrm{cm}^{2}$, jauh lebih rendah dengan angka hasil pengamatan dalam periode yang sama tahun sebelumnya yakni 5,5 spora/ $\mathrm{cm}^{2}$. Pada periode
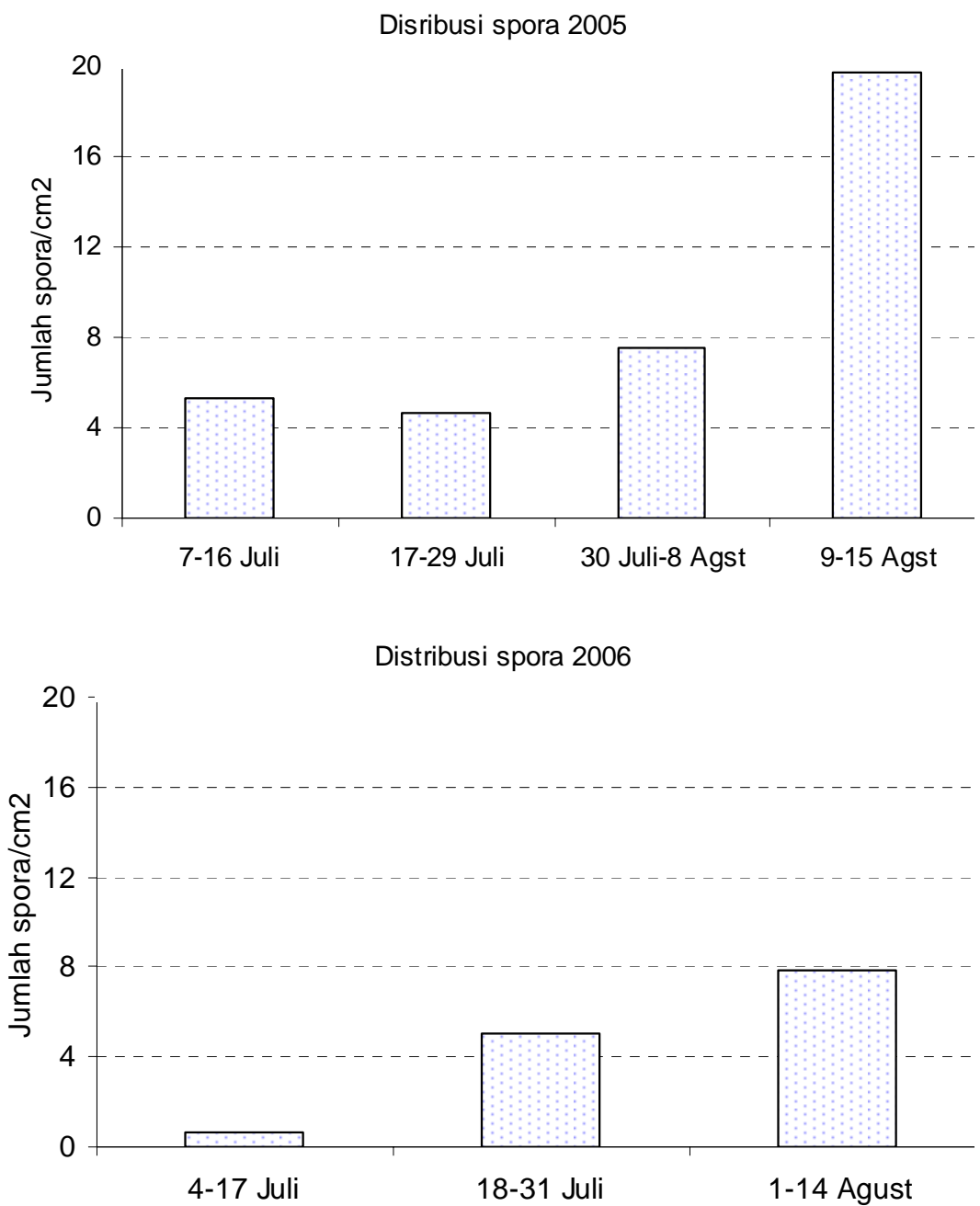

Gambar 4. Rata-rata jumlah spora yang terdistribusi di udara selama tahun 2005 dan 2006 
Agustus 2006 jumlah spora di udara rata-rata adalah $8 \mathrm{spora} / \mathrm{c} \mathrm{cm}^{2}$.

Pola pengguguran daun oleh $C$. cassiicola. Pada pengamatan ini daun yang dihitung adalah hanya daun yang terserang $C$. cassiicola secara dominan. Keparahan penyakit gugur daun di areal penelitian selama periode pengamatan tahun 2005 dan 2006 sangat berbeda (Gambar 5). Pada periode pengamatan tahun 2005 jumlah daun yang gugur relatif tinggi dan berlangsung pada waktu selama pengamatan. Pada pengamatan pertama yakni minggu kedua Juli 2005 jumlah daun yang gugur adalah 65 pada areal seluas $1 \mathrm{~m}^{2}$. Jumlah ini meningkat secara linear pada minggu-minggu selanjutnya hinggá mencapai angka tertinggi yakni 160 daun per $\mathrm{m}^{2}$ pada awal Agustus 2005, jumlah daun yang gugur tetap tinggi ( $>100 \mathrm{daun} / \mathrm{m}^{2}$ ) hingga pertengahan Agustus 2005.

Selama periode pengamatan tahun 2006 daun yang gugur akibat terserang cendawan $C$. cassiicola jauh lebih sedikit. Tidak ada daun yang gugur selama periode Juli 2006. Jumlah yang yang gugur selama Agustus 2006 relatif rendah yakni dibawah 20 daun $/ \mathrm{m}^{2}$.

\section{Pembahasan}

Pertumbuhan tajuk tanaman dan
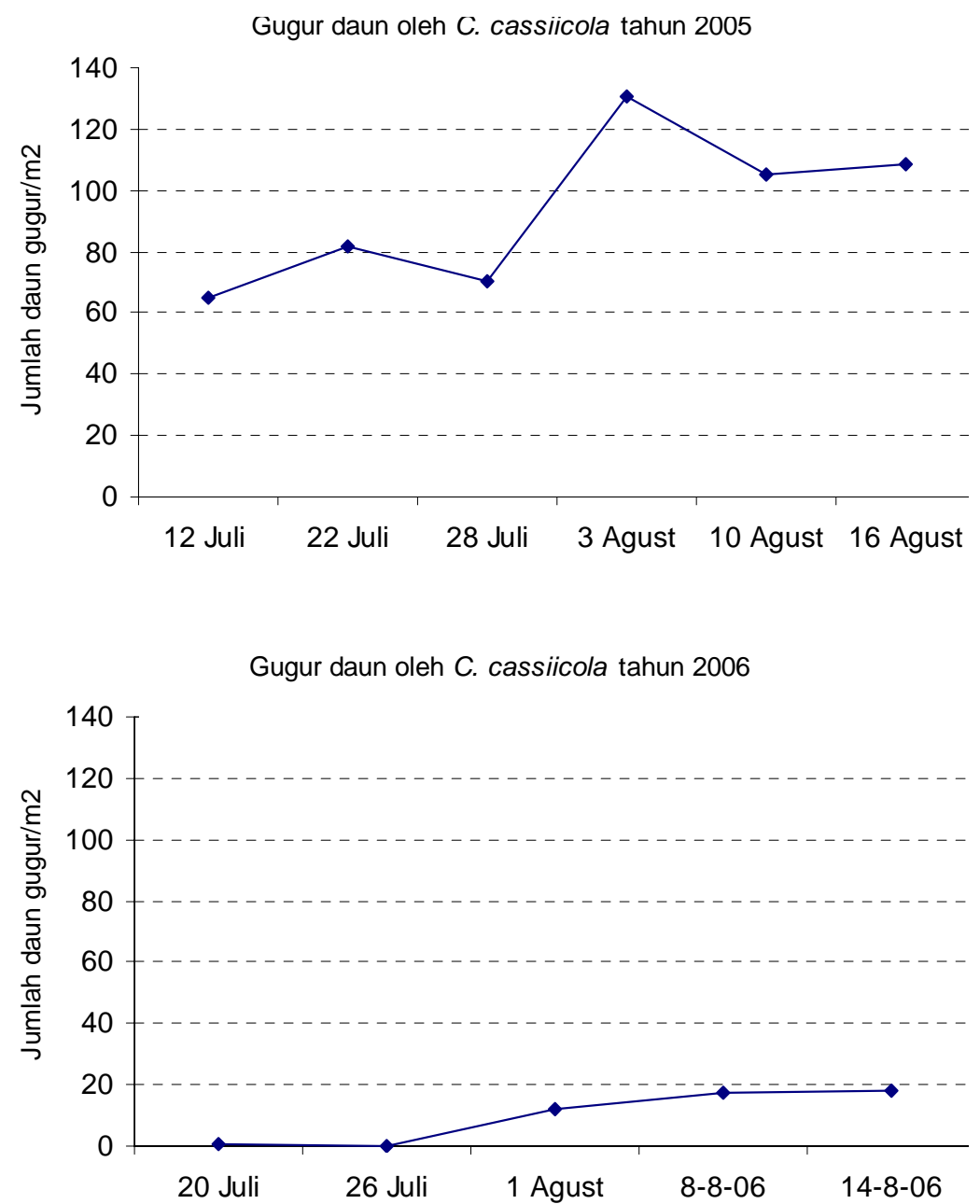

Gambar 5. Jumlah daun yang gugur selama kurun waktu pengamatan tahun 2005 dan 2006 
perkembangan penyakit gugur daun yang disebabkan oleh C. cassiicola diyakini berkaitan erat dengan kondisi cuaca selama Juli dan Agustus 2005 atau 2006. Selama paruh pertama Juli 2005 terjadi hujan dengan curah hujan relatif sedikit dengan selang waktu terjadinya hujan berikutnya sekitar dua hingga tiga hari. Kondisi ini menyebabkan meningkatnya kelembaban udara pada satu sisi dan temperatur juga tinggi. Pada saat ini daun karet basah dan kelembaban berkisar 97-98 persen dengan suhu antara $29^{\circ} \mathrm{C}-31^{\circ}$ C. Kondisi ini merupakan kondisi yang optimal bagi spora untuk berkecambah. Jumlah spora pada keadaan ini berada pada kategori sedang yakni $5,5 \mathrm{spora} / \mathrm{cm}^{2}$. Kondisi di mana ada hujan yang tidak begitu lebat yang diikuti oleh periode tanpa hujan dalam waktu yang relatif lama menjadikan kondisi udara menjadi sangat optimal bagi perkecambahan spora terjadi pada paruh pertama Agustus 2005. Pada periode ini ternyata hujan jatuh setelah mengalami periode tanpa hujan sekitar 8 hari sejak jatuh hujan dengan curah hujan yang kecil yakni hanya $4 \mathrm{~mm} / \mathrm{hari}$. Pada keadaan ini terjadi jumlah spora yang terdistribusi relatif tinggi yakni mencapai angka $19,5 \mathrm{spora} / \mathrm{cm}^{2}$ dibandingkan dengan paruh kedua Juli 2005. Situmorang (1998) melaporkan hal serupa dengan yang ditemukan dalam penelitian ini.

Kondisi cuaca selama periode pangamatan tahun 2006 yakni Juli dan Agustus relatif berbeda bila dibandingkan dengan periode yang sama tahun 2005. Selama paruh pertama Juli 2006 tidak ada hujan sama sekali. Udara tergolong cerah atau temperatur udara tergolong tinggi $\left(33^{\circ} \mathrm{C}\right)$ dengan kelembaban relatif (RH) lebih rendah (<89\%) Kondisi ini menjadi tidak cocok bagi percambahan spora. Konsekuensi dari kondisi cuaca demikian adalah sangat rendahnya jumlah spora di udara yakni kurang dari $1 \mathrm{spora} / \mathrm{cm}^{2}$. Adanya hujan yang terjadi relatif lebat setiap hari selama empat hari pada paruh kedua Juli 2006 menjadikan udara, walaupun relatif lembab dan temperatur udara relatif tinggi, tidak begitu ideal untuk perkecambahan spora. Ini dibuktikan jumlah spora di udara selama paruh kedua Juli dan paruh pertama Agustus 2006 tidak tinggi dan tidak begitu berbeda satu sama lain.,. Rata jumlah spora di udara di kedua periode pengamatan itu berturut-turut 5,5 $\mathrm{mm} / \mathrm{cm}^{2}$ dan $8 \mathrm{~mm} / \mathrm{cm}^{2}$.

Pola curah hujan dan jumlah hari hujan ini tidak saja mempengaruhi keragaman jumlah spora di udara dalam kurun waktu pengamatan yakni Juli dan
Agustus 2005 dan 2006 tetapi juga berpengaruh terhadap jumlah daun yang terinfeksi $C$. cassiicola. Tajuk tanaman dalam bulan-bulan Juli hingga Agustus 2005 dan 2006 relatif sama, di mana pada pertengahan Juli hanya sekitar 40 persen daun yang termasuk stadia hijau. Jumlah daun kategori ini meningkat secara linear hingga minggu pertama Agustus.

Meskipun pola curah hujan dan jumlah hari hujan tidak mempengaruhi secara nyata tajuk tanaman tetapi yang terpenting di sini adalah pengaruh keduanya terhadap keragaman jumlah spora di udara. Nurhayati (2004) melaporkan hasil penelitiannya pada tanaman di kebun Entres bahwa jumlah spora di udara berkorelasi positif dengan tingkat serangan C. cassiicola. Dalam penelitian ini ternyata ditemukan keadaan yang agak mirip. Selama periode pengamatan Juli dan Agustus 2005 jumlah daun yang gugur relatif tinggi yakni mulai dari sekitar 65 daun $/ \mathrm{m}^{2}$ pada pertengahan Juli hingga tetap berada di atas 100 daun per $\mathrm{m}^{2}$ pada tiga periode pengamatan di bulan Agustus 2005. Kontras dengan ini terjadi selama periode pengamatan Juli dan Agustus 2006 di mana daun gugur hanya bulan Agustus 2006 dengan jumlah daun gugur di bawah 20 per $\mathrm{m}^{2}$. Rendahnya jumlah daun yang gugur selama periode ini sangat berakitan erat dengan rendahnya jumlah spora di udara selama periode pengamatan Juli dan Agustus 2006.

Suatu hal yang penting untuk dinyatakan di sini adalah bahwa selama periode pembentukan daun muda tahun 2006 terjadi hujan yang relatif tinggi dan berlangsung dalam jumlah hari hujan lebih dari 6 hari dalam periode 15 hari. Kondisi ini menurut sejumlah peneliti memungkinkan intensifnya pencucian spora, sehingga patogen gagal menginfeksi inangnya.

Hujan apabila tidak terlalu lebat dapat membantu pembebasan atau penyebaran patogen., namun hujan yang terlalu lebat akan mengakibatkan pencucian spora patogen dari permukaan tanaman dan tanah. Hujan yang terus menerus sehingga tanah menjadi terlalu lembab dapat mematikan atau menekan perkembangan patogen demikian juga pada saat musim kemarau yang panjang dapat mengakibatkan tanah menjadi kering sehingga patogen menjadi mati (Situmorang, 1998; Agrios, 1997). 


\section{SIMPULAN}

1. Pola curah hujan dan hari hujan yang sedikit dan berseling dengan cuaca panas mempengaruhi keparahan penyakit gugur daun Corynespora. Jumlah spora di udara relatif lebih tinggi dalam periode pengamatan tahun 2005 dibandingkan dalam periode yang sama tahun 2006, keparahan penyakit gugur daun Corynespora, lebih tinggi pada tahun 2005 dibandingkan dengan 2006

2. Terjadinya epidemi disebabkan oleh pergeseran pola pembentukan daun muda dan pola pergeseran curah hujan. Apabila terjadi hujan dengan intensitas rendah dan berselang-seling dengan hari hujan 6 hari, selama pembentukan daun muda, maka tanaman menghasilkan RRIM 600 akan mengakibatkan terjadinya epidemi.

\section{DAFTAR PUSTAKA}

Agrios, G. N. 1997. Plant Pathology. $4^{\text {th }}$ ed.. Academic Press. , California USA.

Anwar, R, Aidi-Daslin, Suhendry, I and Wulan, S. 2000. Quantifying genetical and environmental factors in determining rubber crop productivity. Hlm. 143-149 dalam: Rasidin Azwar et al , ed. Proc. Indonesian Rubber Conf. and IRRDB Symposium. 2000. Indonesia Rubber Res. Inst..

Darmono, T.W. 2006. Molecular variability on Corynespora cassicola

Www.rothamted.ac.uk/res/corporate/fellows/pro jects/tindonesia. Diakses tanggal 19 maret 2006.

Nurhayati, A. Situmorang., Z.R. Djafar dan Suparman. 2004. Faktor lingkungan dan model peramalan penyakit gugur daun karet Corynespora. Jurnal Lingkungan dan Pembangunan. PP-SML. UI 24(4):243-253.
Nurhayati, A. Situmorang., Z.R. Djafar dan Suparman. 2004. Uji kerentanan daun karet terhadap infeksi Corynespora cassiicola. Dalam: Aron Situmorang et al, ed. Proc. Pertemuan teknis. Pusat Penelitian Karet Balai Penelitian Sembawa

Pawirosoemardjo, S., Purwantara, A. 1987. Sporulation and spore germination of Corynespora cassiicola. Paper pada IRRDB Symposium Pathology of Hevea brasiliensis, November 2-3, 1987. Chiangmai Thailand.

Pawirosoemardjo, S. 2004 Manajemen pengendalian penyakit penting dalam upaya mengamankan target produksi karet nasional tahun 2020. dalam: Aron Situmorang et al, ed. Proc. Pertemuan Teknis. Pusat Penelitian Karet Balai Penelitian Sembawa.

Pusat Penelitian dan Pengembangan Perkebunan Tanjung Morawa (P4TM). 1988. Forum Komunikasi Perkebunan. Balai Penelitian.PT Perkebunan Wilayah II. Sungai karang 25 januari 1988.

Situmorang, A., A. Budiman. 1984. Corynespora cassiicola (Berk \& Curt) Wei penyebab penyakit gugur daun pada karet. Kumpulan makalah lokakarya karet 1984, PN/PT Perkebunan Wilayah-1 dan P4TM. 14-16 Nopember 1984 di Medan. P4TM. 10 hal.

Situmorang, A. 1998. Model hubungan iklim mikro dan epidemiologi penyakit gugur tanaman. Program studi Entomologi dan Fitopatologi Fakultas Pascasarjana IPB. Bogor. 15 hal.

Soepena, H. 1986. Penyakit gugur daun Corynespora pada tanaman karet. Pertemuan Karet dan Kelapa. $\quad$ Semarang 6-7 Februari 1986. Research Centre Getas. PN/PT Perkebunan Salatiga. 